\title{
Field control and biology studies of a new pest species, Aethina tumida Murray (Coleoptera, Nitidulidae), attacking European honey bees in the Western Hemisphere
}

\author{
Patti J. Elzen*, James R. Baxter, David Wèstervelt ${ }^{1}$, \\ Charlotte Randall ${ }^{2}$, Keith S. Delaplane ${ }^{1}$, Laurence Cutts ${ }^{1}$, \\ William T. Wilson
}

USDA-ARS, Kika de la Garza Subtropical Agricultural Research Center, 2413 E. Hwy. 83, Weslaco, TX 78596, USA

(Received 23 March 1999; revised 15 June 1999; accepted 21 June 1999)

\begin{abstract}
The small hive beetle, Aethina tumida Murray, is a nitidulid species newly recorded attacking honey bees in the Western Hemisphere. We initiated field and laboratory tests on the control and biology of this new pest. Very high mortality of adult and larval A. tumida in Florida and Georgia hives resulted from field tests using $10 \%$ coumaphos in plastic strips in trapping devices on the hive bottom: as high as $90.2 \%$ beetle mortality occurred in hives in Florida. Adult beetles were found in the laboratory to feed on honey bee eggs, completely consuming all eggs, even in the presence of honey and pollen. Odors from hive products plus adult bees were found to be significantly attractive to flying adult beetles, as evidenced in baited trap studies. Hive products alone or bees alone were not attractive to adult $A$. tumida. (1) Inra/DIB/AGIB/Elsevier, Paris
\end{abstract}

Aethina tumida / small hive beetle / insecticides / control / honey bee / Apis mellifera / USA / attractants / brood predation

\footnotetext{
* Correspondence and reprints

E-mail: elzenp@rsru2.tamu.edu

${ }^{1}$ Present address: Florida Dept. Agric., Division of Plant Industry, Gainesville, Florida 32614, USA

${ }^{2}$ Randall's Wax Works, Umatilla, Florida 32784, USA

${ }^{3}$ Dept. Entomology, Univ, of Georgia, Athens, Georgia 3060, USA

This article reports the results of research only; mention of a proprietary product does not constitute endorsement by the USDA
} 


\section{INTRODUCTION}

In June of 1998 in east-central Florida an insect species was discovered destroying honey bee, Apis mellifera $\mathrm{L}$., colonies. Adult and larval specimens were sent to M.C. Thomas of the Florida Department of Agriculture for identification. The species was identified as Aethina tumida Murray, the small hive beetle, a coleopteran in the family Nitidulidae [4]. Since that time, adult beetles have been found in Georgia, South Carolina, and North Carolina. These discoveries were the first time A. tumida has been recorded in the Western Hemisphere. The native host range of $A$. tumida is in subSaharan Africa, where it is considered a minor pest of African honey bees [1]. This is in contrast to its observed ability in Florida to destroy entire bee yards in which it has become established. This discovery in Florida is the first known of $A$. tumida attacking European honey bees.

Biology studies conducted in South Africa by Lundie [1] indicated this beetle primarily attacks weakened or small hives, causing little damage to well-established hives. Combs in storage containing honey can also be damaged. Adults and larvae cause damage by burrowing into cells in search of honey and perhaps pollen, possibly fouling the honey by defecating in it. In eastcentral Florida, however, adult and larval A. tumida have been observed infesting and killing what were previously robust hives [2]. We have seen instances (> 100 hives) in which there are more than 1000 adults and several hundred larvae per hive. Fermenting honey often drips from the opened cells, and may produce a slimy film over all hive contents. The honey may then be unfit for human consumption. We observed evidence that the beetle may feed on bee brood.

Spread of this destructive beetle was so greatly feared as to necessitate a temporary quarantine for the state of Florida. Very little information exists on this species within
African literature, and no scientific information exists on A. tumida in the Western Hemisphere.

Because this new species is so destructive in its new habitat and is attacking European honey bees for the first time, we considered it important to immediately devise a means of control of adults and larvae. We also initiated biology studies pertaining to predation of brood, and to beetle attractants.

\section{MATERIALS AND METHODS}

\subsection{Test location}

All studies were conducted in previously identified hives determined to be infested with A. tumida. Voucher specimens were collected and deposited in the Texas A \& M University Insect Collection for possible future reference. Test hives were located in the most heavily infested area in Florida, St. Lucie County, on the east-central coast. An additional site was located in Richmond Hill, Georgia. Hives were not previously treated with any insecticide targeted at controlling the beetle. No live adult or larval A. tumida were transported out of the St. Lucie County or Richmond Hill areas, in an effort to avoid spreading the beetle into new areas.

\subsection{Control studies}

For testing of a candidate compound to control adult and larval $A$. tumida within the hive, a trapping device was constructed and placed on hive bottom boards in the back corner. Lundie [1] found that most beetles congregate on the bottom board in such a site. The device we used consisted of a single $15 \mathrm{~cm} \times 15 \mathrm{~cm}$ piece of corrugated cardboard with one surface stripped off to expose the corrugations. Onto the corrugated side was stapled a single strip of insecticideimpregnated plastic. This device was then stapled onto the bottom board with the treatment strip facing down in the back corner to prevent the bees from removing the device. Control hives received untreated cardboard only. Preliminary results testing various insecticides in the laboratory demonstrated that organophosphate insecticides were effective in killing adult and larval beetles. Coumaphos $10 \%$ strips (Bayer Corp, Shawnee Mission, Kansas, USA), were chosen as 
the candidate chemical owing to its activity in the laboratory and its likelihood of registration for use in honey bee hives for mite (Varroa jacobsoni) control.

In Florida, 17 hives were treated with $10 \%$ coumaphos strips and seven hives were designated as control hives with cardboard only. In Georgia there were 25 coumaphos-treated hives and 14 control hives. Numbers of dead and live adults and larvae in Florida were counted on the bottom boards, both those under the cardboard trap and those moving outside the trap, at 24 and $48 \mathrm{~h}$ after initial coumaphos exposure. In Georgia, live and dead adults were counted at 24 and $48 \mathrm{~h}$; insufficient larvae were present to test. Cardboard pieces were removed at each interval, dead and live adults and larvae were counted, and then the cardboard was re-stapled onto the hive bottom. Percent mortality at each time interval was transformed by the arc-sine equation and compared with control mortality using a twosample unpaired $t$-test [3].

\subsection{Biology studies}

A laboratory study was initiated to test if the small hive beetle would feed on honey bee eggs. Glass pint jars were set up containing one of three treatments: 1) five adult beetles plus a known number of bee eggs in a $5 \times 5 \mathrm{~cm}$ measured area of comb; 2) five adult beetles plus five bees plus a known number of bee eggs in comb; and 3) a control of five bees only with a known number of bee eggs in comb. Honey and pollen were added to all treatments, thus affording beetles a choice in food source. Five replicates of each treatment were held at $26 \pm 3{ }^{\circ} \mathrm{C}$ for $24 \mathrm{~h}$ and then the remaining eggs left in the comb section were counted. Resulting percent egg loss after the $24 \mathrm{~h}$ period were transformed by the arc-sine equation and analyzed by paired $t$-tests [3]

Attractancy of various hive products was field tested in both Florida and Georgia. Traps were constructed with 8-mesh hardware cloth glued across $7 \mathrm{~cm}$ in diameter holes in buckets, large enough for adult beetles to enter, and positioned randomly throughout the infested bee yard. In Florida and Georgia, the following treatments were presented in separate traps: 1) $10 \mathrm{~g}$ of commercially obtained honey plus 5 g commercially obtained pollen; 2) honey plus pollen plus $50 \mathrm{~mL}$ (as measured into a $100 \mathrm{~mL}$ beaker) adult bees; 3 ) bees only; 4) an excised piece of comb from uninfested hives; 5) comb plus honey plus pollen; or 6) an unbaited control. In Florida an additional treatment consisted of $4 \mathrm{~g}$ of brood obtained from uninfested hives. In Georgia an additional treatment consisted of an excised piece of comb collected from beetle-infested hives. All treatments were replicated three to four times at each location. Numbers of adult beetles captured in each trap were recorded at 24 and $48 \mathrm{~h}$ in the early morning at each site. Resulting mean cumulative numbers of captured beetles were compared to unbaited controls with unpaired $t$-tests [3] for the entire trapping period.

\section{RESULTS AND DISCUSSION}

\subsection{Control studies}

Coumaphos strips, when placed under cardboard stapled to the hive bottom board, provided good control of small hive beetle adults and larvae on the bottom boards over the test periods (table I). Figure l shows the treatment device and dead adult beetles. After $24 \mathrm{~h}$ exposure to coumaphos, approximately two-thirds of the adult population on the bottom boards were killed under the traps, with an additional one-quarter killed within the next $24 \mathrm{~h}$. The rate of kill in the Georgia coumaphos-treated hives was also good (table I). Larval rates of mortality showed similar patterns to the adult A. tumida rate of mortality (table I). After $24 \mathrm{~h}$ of exposure to coumaphos, nearly twothirds of the larval population on the bottom boards was killed by the coumaphos, and $34 \%$ of the population was killed in the next $24 \mathrm{~h}$, for a total of $94.2 \%$ mortality. Additionally, previous tests with coumaphos have found it to be non-toxic to bees when $10 \%$ strips were hung directly among broodnest bees (Baxter, unpublished data). It is important to note, however, that even though nearly all larvae on the bottom boards were killed within the $48 \mathrm{~h}$ treatment period, some younger larvae remained on the combs and thus avoided exposure (older larvae enter into a wandering stage, in which they crawl down to bottom boards). It is thus advisable that longer periods of treatment be used to control all larval stages of A. tumida in a hive. 
Table I. Mortality of adult and larval A. tumida under traps on hive bottom boards exposed to coumaphos within the hive.

\begin{tabular}{|c|c|c|}
\hline \multirow[t]{2}{*}{ Treatment } & \multicolumn{2}{|c|}{ Mean cumulative percent mortality $( \pm \mathrm{SE})$} \\
\hline & $24 \mathrm{~h}$ & $48 \mathrm{~h}$ \\
\hline \multicolumn{3}{|l|}{ Adults } \\
\hline Control & 0 & 0 \\
\hline $10 \%$ Coumaphos strips - Florida & $65.9(5.2)^{*}$ & $90.2(1.3)^{*}$ \\
\hline $10 \%$ Coumaphos strips - Georgia & $76.5(8.1)^{*}$ & $85.1(6.8)^{*}$ \\
\hline \multicolumn{3}{|l|}{ Larvae } \\
\hline Control & () & 0 \\
\hline $10 \%$ Coumaphos strips - Florida & $60.2(1.3)^{*}$ & $94.2(5.9)^{*}$ \\
\hline
\end{tabular}

* Denotes significant difference from control $(P<0.05, t$-test $)$.

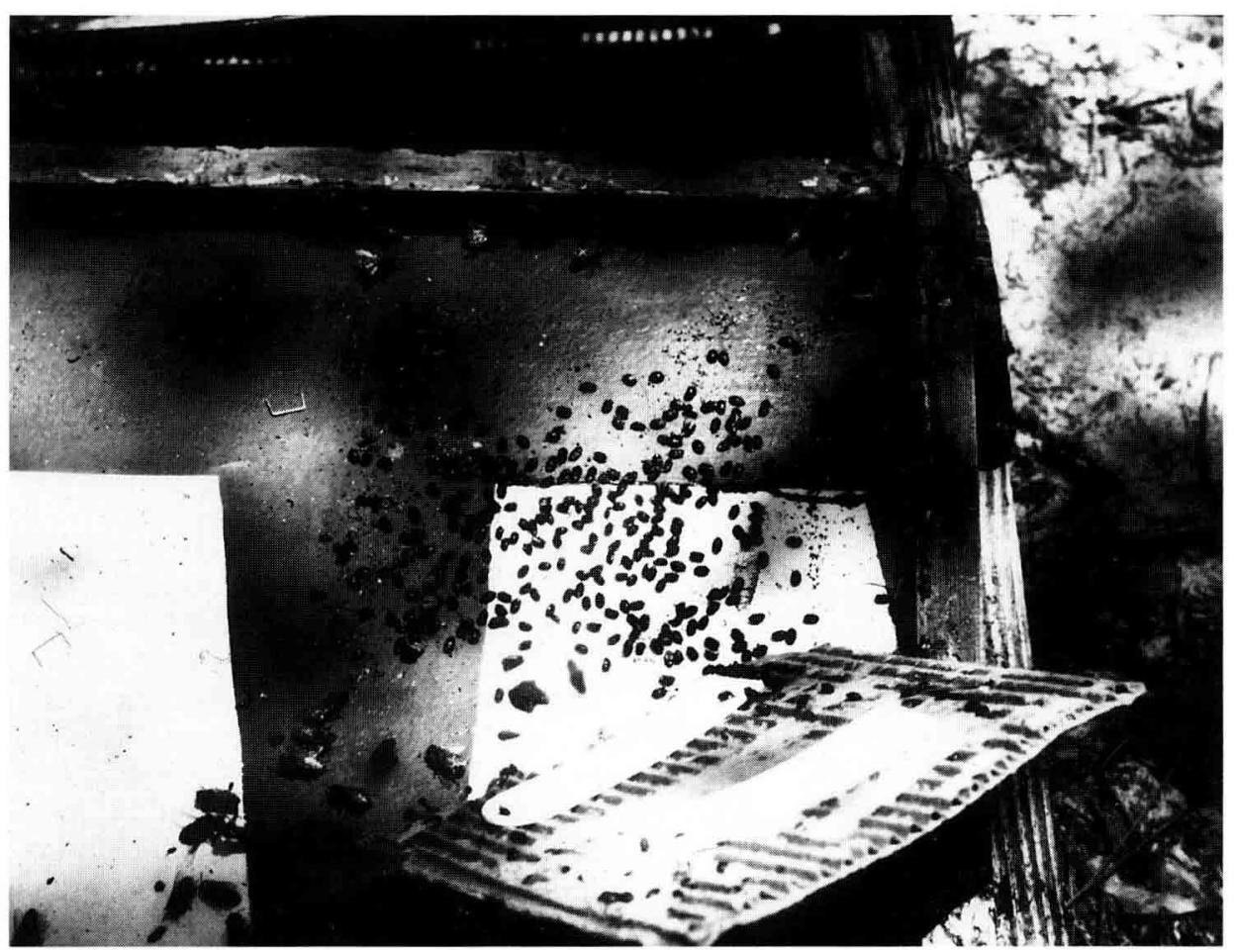

Figure 1. Coumaphos/cardboard treatment device with resulting dead adult A. tumida.

\subsection{Biology studies}

There was evidence of feeding by A. tumida on bee eggs. No eggs remained in the test units containing beetles after the 24 h period (table II). Beetles consumed all eggs present, even in the presence of excess honey and pollen. Observations of hives with heavy $A$. tumida infestations showed very low amounts of brood in both Florida and Georgia. Whether the predation seen in our study explains the low level of brood seen in infested hives, however, cannot automatically be assumed. 
Table II. Number of honey bee eggs in test units with or without adult A. tumida.

\begin{tabular}{lcc}
\hline Treatment & \multicolumn{2}{c}{ Mean no. bee eggs ( $\pm \mathrm{SE})$} \\
\cline { 2 - 3 } & $0 \mathrm{~h}$ & $24 \mathrm{~h}$ \\
\hline Beetles + bee eggs & $12.0(1.0)$ & $0.2(0.2)^{*}$ \\
Beetles + bees + bee eggs & $12.2(1.0)$ & $0 *$ \\
Bees + bee eggs & $12.8(0.4)$ & $12.8(0.4)$ \\
\hline
\end{tabular}

* Denotes significant difference between time 0 and $24 \mathrm{~h}$ within a row $(P<0.05$, paired $t$-test).

Table III. Attractancy of hive odors toward adult A. tumida, Florida and Georgia.

\begin{tabular}{lcc}
\hline Treatment & \multicolumn{2}{c}{ Mean cumulative no. adult beetles $( \pm$ SE) } \\
\cline { 2 - 3 } & Florida & Georgia \\
\hline Honey + pollen & 0 & 0 \\
Honey + pollen + adult bees & $9.0(4.5)^{*}$ & $6.3(3.0)^{*}$ \\
Adult bees & $1.3(0.8)$ & $0.3(0.4)$ \\
Uninfested comb & 0 & 0 \\
Comb + pollen + honey & 0 & 0 \\
Brood & 0 & - \\
Infested comb & - & 0 \\
Control & 0 & 0 \\
\hline
\end{tabular}

* Significantly different compared to control $(P<0.05, t$-test $)$.

Results of the trial testing attractancy of various hive products and/or bees showed definite and repeatable outcomes (table III). In both Florida and Georgia, it was the combination of hive products (honey and pollen) plus live adult bees that was most attractive to adult $A$. tumida. Hive products alone, or bees alone, were not significant attractants to adult beetles. Adult beetles were attracted to pollen/honey plus bees even though the traps were set up amongst hives with such odors permeating the bee yard. It is important to note that we used hive products and bees from sources that had no prior contact with larval or adult beetles, i.e. there were no possible beetle pheromones on the hive products or bees. There was no attraction to comb obtained from infested hives.
The reason A. tumida has become a serious threat to USA beekeeping but is considered only a minor pest in South Africa is unknown at this time. An important possible explanation for this is that $A$. tumida has never before been recorded attacking European honey bee hives in the Western Hemisphere, whereas in South Africa A. tumida must contend with the more aggressive African and Cape bees.

Further research planned includes studies of natural control factors, possible aggregation pheromones, and other potential insecticidal control measures. Efforts will be made to study $A$. tumida in its native habitat to look for clues as to why it remains only a minor pest in South Africa. With the information presented in this paper we feel 
that effective control measures are now available to treat $A$. tumida within the hive without endangering the resident bee population. Some aspects of the basic biology of A. tumida in the Western Hemisphere are also provided.

Résumé - Lutte sur le terrain et étude biologique d'un nouvel ennemi des abeilles (A. mellifera) sur le continent américain : Aethina tumida Murray (Coleoptera, Nitidulidae). La forme adulte d'Aethina tumida, ou petit coléoptère de la ruche, a été enregistrée officiellement en 1998 dans les états de Floride, Géorgie, Caroline du Nord et Caroline du Sud. Nous avons lancé des études sur le terrain et au laboratoire concernant la lutte et la biologie de ce nouvel ennemi des abeilles. Nous avons utilisé un piège constitué d'un carré de carton ondulé $(15 \mathrm{~cm} \times 15 \mathrm{~cm})$, dont l'une des faces a été ôtée. Des bandelettes en plastique imprégnées d'une solution de coumaphos à $10 \%$ ont été agrafées sous la face ondulée et le tout a été fixé sur le plancher des ruches. Les études de terrain ont montré que ce dispositif permettait de tuer jusqu'à 90,2\% des adultes et jusqu'à 94,2\% des larves (tableau I). L'alimentation des adultes sur le couvain d'abeilles a été étudiée au laboratoire. Sur une période de $24 \mathrm{~h}$ les adultes ont consommé tous les æufs d'abeilles présents, même si du miel et du pollen leur était fourni en excès. Dans les études de terrain sur l'attractivité des odeurs de la ruche visà-vis des adultes en vol, les odeurs combinées des produits de la ruche et des abeilles adultes se sont montrées les plus attractives (tableau III). Les produits de la ruche seuls et les abeilles adultes seules n'ont pas présenté d'attraction significative. Des pistes de recherche sur la lutte biologique et les phéromones d'agrégation sont proposées. (C) Inra/DIB/AGIB/Elsevier, Paris

Aethina tumida / Coleoptera / lutte chimique / prédation couvain / attractivité / Apis mellifera
Zusammenfassung - Bekämpfung und biologische Studien eines neuen Schädlings, Aethina tumida Murray, in europäischen Bienenvölkern der westlichen Hemisphäre. Der Glanzkäfer Aethina tumida ist ein neuer Schädling von Völkern der Honigbienen in der westlichen Hemisphäre. Adulte A. tumida wurden 1998 amtlich in Florida, Georgia, Suid- und NordCarolina festgestellt. Wir begannen mit Feldund Laborstudien, um Bekämpfung und die Biologie dieses neuen Parasiten zu untersuchen. Bei der Feldbekämpfung zeigte sich, dass man mit $10 \%$ Coumaphos imprägnierten Plastikstreifen unter Wellpappe geheftet bis zu 90,2 \% der Käfer abtöten kann. Diese Coumaphos-Fallen töteten ausserdem bis zu 94,2 \% der wandernden Larven. In einem Labortest über das Fressverhalten zeigte sich, dass adulte Käfer innerhalb von 24 Stunden offensichtlich alle Bieneneier frassen, obwohl Honig und Pollen im Übermass geboten wurden. In Feldversuchen über die Attraktivität von Volksgeruch auf vorbei fliegende Käfer erwies sich die Kombination von Bienenerzeugnissen und adulten Bienen als attraktivstes Lockmittel; Bienenprodukte bzw. adulte Bienen allein waren nicht signifikant attraktiv. (C) Inra/DIB/AGIB/Elsevier, Paris

Aethina tumida / Bienenschädling / Insektizide / Bekämpfung / Apis mellifera / Lockstoffe / Brutfrass

\section{REFERENCES}

[1] Lundie A.E., The small hive beetle, Aethina tumida, Sci. Bull. 220, Union of South Africa, Department of Agriculture and Forestry, 1940, 30 pp.

121 Sanford M.T., Aethina tumida: a new beehive pest in the Western Hemisphere, APIS 16 (1998) $1-5$.

[3] Steel R.G.D., Torrie J.H., Principles and Procedures of Statistics, 2nd ed, McGraw-Hill, New York, 1980.

14] Thomas M.C., Pest alert: small hive beetle, Am Bee J. 138 (1998) 565. 